RESEARCH PAPER RP1430

\author{
Part of Journal of Research of the National Bureau of Standards, Volume 27, \\ November 1941
}

\title{
REFLECTION-TRANSMISSION RELATIONSHIPS IN SHEET MATERIALS
}

\author{
By Herbert F. Launer
}

\section{ABSTRACT}

Reflectances of transmissive sheets, calculated from the transmissions of one and two sheets, are compared with reflectances obtained by using the General Electric Recording Spectrophotometer. The expression used as a basis for calculation, $\left.R_{a}=\sqrt{1-\left(T_{a}^{2} / T_{2 a}\right.}\right)$, in which $R_{a}$ is the reflectance, and $T_{a}$ and $T_{2 a}$ are the transmissions of one and two sheets, respectively, of $a$, was derived by considering the infinite series of reflections undergone by light, or radiant energy in general, in passing through the two sheets. The expression was found to be valid and useful over a wide range of reflectances and wavelengths, for materials such as paper, glass, and an organic plastic.

The method is an absolute one, since it involves no reflectance standard. It involves no spherical or similar integrating device, nor does it involve any reflecting surface other than that of the sample itself, as a fundamental part of the measurements. When transmission values for diffuse incidence are substituted into the expression, the reflectances thus calculated correspond to the conditions of diffuse incidence and diffuse viewing, and as such are somewhat higher than the usual directly measured reflectances for normal incidence and diffuse viewing (or diffuse incidence and normal viewing). For clear sheets, with normal incidence, specular refiectance may be calculated.

The method thus affords a means of determining, from two simple measurements, the specular-plus-diffuse reflectance of transmissive sheets for diffused light or radiant energy in general.

The expression as derived is theoretically inapplicable to diffusing sheets for light of normal incidence, but a compensation of errors allows close agreement over the visible range, at 365 millimicrons, and for "white" light, for all except tissue paper and other materials of like transmissivity.

For diffuse incidence at 365, and to a certain extent, at 405 millimicrons, some papers show deviations from the simple theory because of fluorescence effects. This and other effects are discussed.

Reflectances in the infrared region near 850 millimicrons are also calculated but no standard for comparison is available for these values. The sources of errors at the shorter wavelengths, however, do not interfere in the infrared region.

Transmissions of papers were found to be dependent upon the angle of incidence.

Reflectances throughout the visible region, measured at $45^{\circ}$ from normal incidence, were found to agree closely, for the type of papers studied, with those obtained using the General Electric Recording Spectrophotometer, which corresponds to the conditions of normal incidence and diffuse viewing. 
I. Introduction

II. Samples studied._.

III. Apparatus

1. Photoelectric equipment

2. Light sources and filters

IV. Experimental results and theoretical discussion

1. Methods of direct measurement of reflectance $\ldots \ldots \ldots \ldots 33$

2. Effect of reflectance of the measuring cell

3. Calculated reflectances for diffuse and normal incidence $\ldots \ldots \ldots$

4. Effect of thickness of sheets.

5. Effect of fluorescence.

6. Results obtained by using heterogeneous ("white") light and infrared..... 441

V. References 441

\section{INTRODUCTION}

In a current study of the photochemistry of paper it was necessary to determine the absolute total reflection and transmission factors of the sheets to permit calculation of the fractional light absorption. The measurement of transmission was relatively simple, but the determination of absolute reflectance, in, for example, the near infrared, for which no reflectance standard is available, led to a consideration of absolute methods. Gibson [1] $]^{1}$ and Van den Akker [2] have recently reviewed various phases of spectrophotometry, particularly with respect to the problems of the reflectance standards and geometrical design of instruments which yield values in terms of a standard magnesium oxide, or similar, surface. Taylor [3] has described an absolute reflectometer in which magnesium oxide (or similar) surfaces play a fundamental part in the measurement, but not in the calculation, of diffuse reflectance. No method, however, has been shown to yield absolute reflectance of diffusing materials, which does not involve, either explicitly or implicitly, the reflectance of either a standard or of the surface of an integrating sphere.

For transmissive materials in sheet form a method suggests itself for obtaining absolute reflectance without involving a standard or any other reflecting surface. Consider light, or radiant energy in general, passing through two sheets of any material, $a$, having the reflection and transmission factors $R_{a}$ and $T_{a}$, corresponding to a definite kind of light. For unit incident flux, the light immediately after transmission by the first sheet has a flux equal to $T_{a}$. This light then undergoes an infinite series of reflections between the two sheets, so that the flux incident upon the second sheet is $T_{a} /\left(1-R_{a}^{2}\right)$, which after transmission through the second sheet becomes $T_{a}^{2} /\left(1-R_{a}^{2}\right)$. Equating this to $T_{2 a}$, the transmission of the two sheets, and transposing, the following expression is obtained:

$$
R_{a}=\sqrt{1-\frac{T_{a}^{2}}{T_{2 a}}}
$$

If the two sheets differ, the expression becomes

$$
R_{a} R_{b}=1-\frac{T_{a} T_{b}}{T_{a b}}
$$

1 Figures in brackets indicate the literature references at the end of this paper. 
Equation 1 was derived in its present form by Gurevich [4], and Smith [5] and in other forms by Stokes [6], Channon, Renwick, and Storr [7], and Ryde and Cooper [8], for diffusing materials, and by Benford [9] for sheets of glass. The expression, however, has apparently not been tested experimentally.

Gurevich assumed the expression to be valid and used it to calculate reflectances of some paper samples in heterogeneous light, but he presented no directly measured reflectances to allow a comparison. Also using heterogeneous light, Kubelka and Munk [10], Steel [11], and Judd [12] studied the relationships between reflectance, thickness, and scattering for papers and other diffusing materials.

The experimental verification of eq 1 is of interest for various reasons. Aside from the value of an absolute method based upon principles entirely different from those of existing methods, it would permit the determination of the reflectance of transmissive sheets from relatively simple transmission measurements, using inexpensive equipment and weak sources of light, without amplification in the measuring system since practically all of the transmitted light is to be measured directly.

In the present paper, reflectances obtained by direct measurement, for a variety of materials, at various wavelengths, are compared with reflectances calculated from transmission measurements of one and two sheets, using eq 1. Various factors causing deviations from the simple theory, such as changes in the values of $R_{a}$ and $T_{a}$ resulting from changes in spectral and geometric distribution of the light by the first sheet are discussed.

\section{SAMPLES STUDIED}

Six papers were selected for study which had been produced in the paper mill at the National Bureau of Standards from a wide variety of commercial materials to secure various representative types of papers. The data significant for the optical properties are listed in the tables; further details as to the papers may be obtained from the publication by Shaw and O'Leary [13]. Three widely differing commercial papers - namely, a tissue paper, a bluish-tint writing paper, and a heavily filled cigarette paper-were also studied. All of the papers had a matte finish. A relatively thick sheet of an organic plastic, a urea-formaldehyde laminated with very thin paper, was included in the investigation, as was a sheet of photographic plate glass.

\section{APPARATUS}

\section{PHOTOELECTRIC EQUIPMENT}

The photoelectric circuit used was that described by Brice [14]. Two General Electric "Light-Sensitive" cells were used, one of which measured the radiant energy transmitted by the sheets and the other of which compensated for lamp fluctuations. A galvanometer having a sensitivity of $0.5 \mu \mathrm{v} / \mathrm{mm}$ and a calibrated potentiometer of $100 \mathrm{ohms}$ total resistance, capable of being read to the nearest 0.1 -percent transmission, completed the circuit. With this arrangement transmission values could be estimated to the nearest 0.05 -percent transmission.

The maximum flux density used corresponded to a photocurrent of $5 \mu \mathrm{a}$ or less, thus making for conditions of highest accuracy, as found 
by Brice. The apparatus was checked for accuracy by measuring the transmission of a polished glass, found by the Photometry and Colorimetry Section to transmit 16.0 percent at a certain wavelength, and by measuring the transmissions of two sectored disks transmitting 25.0 and 50.0 percent. The results showed that the probable error was less than 0.1-percent transmission.

The measuring cell was adapted for transmission measurements by removing the photosensitive selenium-covered steel plate from the hard-rubber case. The plate was mounted on a flat, hard-rubber surface, and the transmission samples were held under spring tension directly against the photosensitive surface by a flat metal frame, the opening of which was slightly larger than the photosensitive surface. Electric contact with the plate was made on the back by two springs extending through holes drilled in the hard rubber. On the front surface contact was made by thin $(0.0005$-in.) silver foil, two strips of which covered the roughened borders and were held under tension against them by the frame. Thus the spacing between the receiving surface and the transmission samples was actually 0.0005 in. under the frame.

For the experiments with diffuse radiant energy, a sheet of paper, No. 198, 20 by $20 \mathrm{~cm}$, which was mounted $38 \mathrm{~mm}$ in front of the cell, 19 by $41 \mathrm{~mm}$, used for transmission measurements, served as a diffusing screen. Multiple reflections between this screen and the sample being studied can be shown to introduce negligible errors into the calculated reflectances. The light source was placed at distances of 35 to $60 \mathrm{~cm}$ from the diffusing screen. For experiments with normal (perpendicular) illumination this diffusing screen was removed.

\section{LIGHT SOURCES AND FILTERS}

Spectrally homogeneous radiant energy was obtained by isolating mercury lines from a 400-watt, "high-intensity" glass-enclosed commercial mercury-vapor lamp. The far red, infrared, and "short" ultraviolet regions were removed by a $15-\mathrm{mm}$ thickness of 0.117 molar $\mathrm{CuCl}_{2} \cdot 2 \mathrm{H}_{2} \mathrm{O}$ (2 percent) solution in a glass cell. Using this filter with the following glass filters, various $\mathrm{Hg}$ lines were isolated, respectively: Corning $986(7 \mathrm{~mm}), 365 \mathrm{~m} \mu$; Corning Noviol $\mathrm{O}$ and 597 , $405 \mathrm{~m} \mu$; Noviol A and 585, $436 \mathrm{~m} \mu$; Jena OG1, Corning 512, and Corning G584J, $546 \mathrm{~m} \mu$; Jena RG1, $623 \mathrm{~m} \mu$. The light thus isolated was not perfectly homogeneous in all cases. As an example, the bright 436 line was faintly contaminated with the 492 line, but not sufficiently so as to affect the results seriously. In no case, however, did the red and infrared, also transmitted by the Corning filters Nos. 986,597 , and 585 , correspond to more than 0.05 percent of the cell response. For "white" light a 110-volt, 100-watt tungsten incandescent lamp, in combination with the cupric chloride filter, was used. For the infrared, a 110-volt, 1,000-watt "Airway Beacon" incandescent lamp, in combination with a Corning 254 filter and a $15-\mathrm{mm}$ layer of water, was used. The effective wavelength of the infrared thus isolated was approximately $850 \mathrm{~m} \mu$, calculated as the spectral centroid from the spectral distribution of the lamp (maximum at $900 \mathrm{~m} \mu$ ), the transmission of the filter, and the spectral sensitivity of the cell (manufacturers' data). 


\section{EXPERIMENTAL RESULTS AND THEORETICAL DISCUSSION}

\section{METHODS OF DIRECT MEASUREMENT OF REFLECTANCE}

The test of eq 1 consists in comparing reflectances calculated from transmission values with directly measured reflectances. The values obtained by using the General Electric Recording Spectrophotometer, which employs the principle of normal incidence and diffuse viewing, were adopted as the basis for all of the directly measured reflectances. Not all of the reflectances were obtained in this manner, but the results obtained by an alternate method were found to be the same, within the limits of the experimental errors of both methods, for the papers included in this study.

The alternate method was the familiar one of normal incidence and $45^{\circ}$ viewing. Light of the desired wavelength was focused on the paper or standard $\mathrm{MgO}$ surface to give an image of 2 by $4 \mathrm{~cm}$. A General Electric cell to receive reflected light was mounted at a distance of $15 \mathrm{~cm}$ from the light spot. Another cell, illuminated by reflection from a piece of clear glass placed at an angle in the incident beam, compensated for lamp fluctuations, as previously described. The $\mathrm{MgO}$ surface was freshly deposited to approximately $3 / 4-\mathrm{mm}$ thickness on a slab of duralumin held in the smoke of burning magnesium ribbon.

The values obtained by using these two direct methods are compared in table 1 for part of the papers included in this study. Parts of the same sheets, but not identical areas thereof, were measured in both cases. The agreement, however, is seen to be satisfactory, and independent of the wavelengths studied. Since both methods yield values relative to $\mathrm{MgO}$, the reflectances were converted to absolute ones by the use of Preston's [15] factors for $\mathrm{MgO}$.

TABLE 1.-Comparison between reflectances of papers obtained from curves using the General Electric Recording Spectrophotometer, and those obtained by measuring reflectances at $45^{\circ}$ fron normal incidence

\begin{tabular}{|c|c|c|c|c|c|c|c|c|}
\hline \multirow{3}{*}{ Paper No. } & \multicolumn{8}{|c|}{ Reflectances at- } \\
\hline & \multicolumn{2}{|c|}{$405 \mathrm{~m} \mu$} & \multicolumn{2}{|c|}{$436 \mathrm{~m}_{\mu}$} & \multicolumn{2}{|c|}{$546 \mathrm{~m}_{\mu}$} & \multicolumn{2}{|c|}{$623 \mathrm{~m}_{\mu}$} \\
\hline & G. E. & $45^{\circ}$ & G. E. & $45^{\circ}$ & G. E. & $45^{\circ}$ & G. E. & $45^{\circ}$ \\
\hline $\begin{array}{l}1215 \\
1214 \\
1191 \\
1130 \\
1136\end{array}$ & $\begin{array}{l}\% \\
76.9 \\
66.5 \\
73.2 \\
63.0 \\
50.5 \\
54.6\end{array}$ & $\begin{array}{l}\% \\
77.1 \\
65.6 \\
73.6 \\
62.4 \\
50.4 \\
55.6\end{array}$ & $\begin{array}{l}\% \\
78.6 \\
69.5 \\
75.8 \\
67.9 \\
56.2 \\
61.4\end{array}$ & $\begin{array}{l}\% \\
78.1 \\
69.9 \\
75.8 \\
67.3 \\
57.6 \\
62.5\end{array}$ & $\begin{array}{l}\% \\
81.2 \\
73.6 \\
79.3 \\
73.2 \\
65.9 \\
71.9\end{array}$ & $\begin{array}{c}\% \\
81.2 \\
74.2 \\
79.6 \\
73.2 \\
66.8 \\
72.9\end{array}$ & $\begin{array}{l}\% \\
81.2 \\
73.8 \\
79.7 \\
73.6 \\
68.2 \\
74.1\end{array}$ & $\begin{array}{l}\%_{81.2} \\
73.1 \\
78.7 \\
72.2 \\
67.4 \\
73.7\end{array}$ \\
\hline
\end{tabular}

The spectrophotometer values at the wavelengths $405,436,546$, and $623 \mathrm{~m} \mu$ were taken from curves obtained by H. J. Keegan, of the Photometry and Colorimetry Section, for samples Nos. 1215, $1214,1191,1170,1133,1136$, and 200 . The values were reduced in the manner described by Gibson and Keegan [16]. All other reflectances were determined by the alternate method, with the exception 
of that of the glass, which was calculated from the refractive index $n=1.5157$ obtained by C. A. Faick, of the Glass Section, for yellow light.

\section{EFFECT OF REFLECTANCE OF THE MEASURING CELL}

In measuring the transmission of sheets held very close to the photosensitive surface, the small amount of radiant energy reflected by this surface must be taken into account. This may be done by considering separately the optical relationships involved for one and two sheets. By summing up the infinite series of reflections between one sheet and the cell surface, the following expression is obtained:

$$
T_{a}=t_{a}\left(1-R_{a} R_{c}\right) .
$$

Similarly, for two sheets:

$$
T_{2 a}=\frac{t_{2 a}\left(1-R_{a} R_{c}\right)}{1+t_{2 a} R_{a} R_{c}},
$$

where $T_{a}$ and $T_{2 a}=$ corrected transmissions of one and two sheets, $t_{a}$ and $t_{2 a}=$ measured transmissions of one and two sheets, and $R_{a}$ and $R_{c}=$ reflectances of the sheet and the cell.

Equations 3 and 4 are then substituted into eq 1 and the following complete expression is obtained:

$R_{a}=\sqrt{\left(1-\frac{t_{a}{ }^{2}}{t_{2 a}}\right)\left(\frac{1}{1-t_{a}{ }^{2} R^{2}}\right)+\left[\frac{R_{c}}{2}\left(\frac{t_{a}{ }^{2}}{t_{2 a}}\right) \frac{1-t_{2 a}}{1-t_{a}{ }^{2} R_{c}{ }^{2}}\right]^{2}}+\frac{R_{c}}{2}\left(\frac{t_{a}{ }^{2}}{t_{2 a}}\right) \frac{1-t_{2 a}}{1-t_{a}{ }^{2} R_{c}{ }^{2}}$.

For usual values of $R_{c}$ (near 0.1 ) eq 5 may be simplified by omitting negligible terms:

$$
R_{a}=\sqrt{1-\frac{t_{a}^{2}}{t_{2 a}}}+0.002+\frac{1}{2} R_{c}\left(\frac{t_{a}^{2}}{t_{2 a}}\right)\left(1-t_{2 a}\right) .
$$

The figure 0.002 applies for most papers but reaches a value of 0.004 for the more transmissive diffusing sheets.

For materials having low transmissions, as do some papers in the ultraviolet and violet, $t_{2 a}$ becomes very small, less than 0.01 , and the errors correspondingly large. To avoid this, a more transmissive, auxiliary sheet may be used in combination with the sheet to be measured, instead of two sheets of the same material. For this case, eq 2 is used and becomes

$$
R_{b}=\frac{1}{R_{a}}\left(1-\frac{T_{a} t_{b}}{t_{a b}}\right)
$$

where $R_{a}=$ reflectance of auxiliary sheet, as calculated from eq 6 , or otherwise known;

$T_{a}=$ corrected transmission of auxiliary sheet, calculated from eq 3 ;

$t_{b}=$ measured transmission of sheet whose reflectance is being determined; and

$t_{a b}=$ measured transmission of the combination, with sheet $b$ between $a$ and the cell. 
TABLE 2.-Reflectances, calculated from the transmissions of one and two sheets, compared with the reflectances directly measured with a General Electric Recording Spectrophotometer a and other equipment

Number and type of sheet material

1215 d-rag paper; $14 \% \mathrm{CaCO}_{3}$ filler; $0.0036^{\prime \prime}$

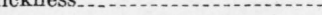
1214 -rag paper; no filler; $0.0038^{\prime \prime}$ thickness 1191 -rag paper; $14 \%$ clay filler; $0.0036^{\prime \prime}$ thickness 1170-Wood pulp paper; $14 \%$ clay fillor 1133-yellowish wood pulp paper; no filler; $0.0035^{\prime \prime}$ thickness pulp paper; no filler; 1136-yellowish wood pulp paper; $9 \%$ clay filler; $0.0037^{\prime \prime}$ thickness . ................... 128-bluish tint rag bond paper; 0.004" thickness_................... 1002-cigarette paper; $19 \% \mathrm{CaCO}_{3}$ filler

0.0015 thickness

198- facing tissue; 0.001 " thickness-

202-clear glass plate; $0.047^{\prime \prime}$ thickness.....

a Used for values at $623,546,436$, and $405 \mathrm{~m}_{\mu}$ for samples $1215,1214,1191,1170,1133$,

1136 , and 200. See text for details.

b Wavelength approximately $850 \mathrm{~m} \mu$. See text for details.

Heterogeneous light was that from a 100-watt, 110-volt tungsten lamp, after trans-

mission through a $15-\mathrm{mm}$ layer of $0.117 M$ cupric chloride solution.

d The first 6 papers were made in the Bureau paper mill [13]. Nos. 128 and 198 were
Reflectances at-

\begin{tabular}{|c|c|c|c|c|c|c|c|c|c|c|c|c|c|c|c|c|c|c|}
\hline \multicolumn{3}{|c|}{$623 \mathrm{~m} \mu$} & \multicolumn{3}{|c|}{$546 \mathrm{~m} \mu$} & \multicolumn{3}{|c|}{$436 \mathrm{~m} \mu$} & \multicolumn{3}{|c|}{$405 \mathrm{~m} \mu$} & \multicolumn{3}{|c|}{$365 \mathrm{~m} \mu$} & \multicolumn{2}{|c|}{ Infrared $b$} & \multicolumn{2}{|c|}{$\begin{array}{l}\text { Heteroge- } \\
\text { neous } \\
\text { ("white") } \\
\text { light o }\end{array}$} \\
\hline $\begin{array}{c}\text { Di- } \\
\text { rect } \\
\text { meas- } \\
\text { ure- } \\
\text { ment }\end{array}$ & \multicolumn{2}{|c|}{$\begin{array}{l}\text { Calculated } \\
\text { from trans- } \\
\text { missions }\end{array}$} & \multirow{2}{*}{ 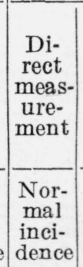 } & \multicolumn{2}{|c|}{$\begin{array}{l}\text { Calculated } \\
\text { from trans- } \\
\text { missions }\end{array}$} & \multirow{2}{*}{$\begin{array}{c}\begin{array}{c}\text { Di- } \\
\text { rect } \\
\text { meas- } \\
\text { ure- } \\
\text { ment }\end{array} \\
\begin{array}{c}\text { Nor- } \\
\text { mal } \\
\text { inci- } \\
\text { dence }\end{array}\end{array}$} & \multicolumn{2}{|c|}{$\begin{array}{l}\text { Calculated } \\
\text { from trans- } \\
\text { missions }\end{array}$} & \multirow{2}{*}{$\begin{array}{c}\text { Di- } \\
\text { rect } \\
\text { meas- } \\
\text { ure- } \\
\text { ment } \\
\text { Nor- } \\
\text { mal } \\
\text { inci- } \\
\text { dence }\end{array}$} & \multicolumn{2}{|c|}{$\begin{array}{l}\text { Calculated } \\
\text { from trans- } \\
\text { missions }\end{array}$} & \multirow{2}{*}{$\begin{array}{c}\text { Di- } \\
\text { rect } \\
\text { meas- } \\
\text { ure- } \\
\text { ment } \\
\\
\begin{array}{c}\text { Nor- } \\
\text { mal } \\
\text { inci- } \\
\text { dence }\end{array}\end{array}$} & \multicolumn{2}{|c|}{$\begin{array}{c}\text { Calculated } \\
\text { from trans- } \\
\text { missions }\end{array}$} & \multicolumn{2}{|c|}{$\begin{array}{l}\text { Calculated } \\
\text { from trans- } \\
\text { missions }\end{array}$} & $\begin{array}{l}\text { Di- } \\
\text { rect } \\
\text { meas- } \\
\text { ure- } \\
\text { ment }\end{array}$ & \begin{tabular}{|c} 
Cal- \\
cu- \\
lated \\
from \\
trans- \\
mis- \\
sions
\end{tabular} \\
\hline $\begin{array}{c}\text { Nor- } \\
\text { mal } \\
\text { inci- } \\
\text { dence }\end{array}$ & $\begin{array}{l}\text { Nor- } \\
\text { mal } \\
\text { inci- } \\
\text { dence }\end{array}$ & $\begin{array}{l}\text { Dif- } \\
\text { fuse } \\
\text { inci- } \\
\text { dence }\end{array}$ & & $\begin{array}{l}\text { Nor- } \\
\text { mal } \\
\text { inci- } \\
\text { dence }\end{array}$ & $\begin{array}{l}\text { Dif- } \\
\text { fuse } \\
\text { inci- } \\
\text { dence }\end{array}$ & & $\begin{array}{l}\text { Nor- } \\
\text { mal } \\
\text { inci- } \\
\text { dence }\end{array}$ & $\begin{array}{l}\text { Dif- } \\
\text { fuse } \\
\text { inci- } \\
\text { dence }\end{array}$ & & $\begin{array}{c}\text { Nor- } \\
\text { mal } \\
\text { inci- } \\
\text { dence }\end{array}$ & \begin{tabular}{|l} 
Dif- \\
fuse \\
inci- \\
dence
\end{tabular} & & $\begin{array}{l}\text { Nor- } \\
\text { mal } \\
\text { inci- } \\
\text { dence }\end{array}$ & \begin{tabular}{|l|} 
Dif- \\
fuse \\
inci- \\
dence
\end{tabular} & $\begin{array}{c}\text { Nor- } \\
\text { mal } \\
\text { inci- } \\
\text { dence }\end{array}$ & $\begin{array}{l}\text { Dif- } \\
\text { fuse } \\
\text { inci- } \\
\text { dence }\end{array}$ & $\begin{array}{l}\text { Nor- } \\
\text { mal } \\
\text { inci- } \\
\text { dence }\end{array}$ & $\begin{array}{l}\text { Nor- } \\
\text { mal } \\
\text { inci- } \\
\text { dence }\end{array}$ \\
\hline $\begin{array}{c}\% \\
81.2\end{array}$ & $\begin{array}{l}\% \\
80.7\end{array}$ & $\begin{array}{c}\% \\
81.8\end{array}$ & $\begin{array}{c}\% \% \\
81.2\end{array}$ & $\begin{array}{l}\% \\
81.4\end{array}$ & $\begin{array}{c}\% \\
82.4\end{array}$ & $\begin{array}{c}\% \\
78.6\end{array}$ & $\begin{array}{l}\% \\
78.3\end{array}$ & $\begin{array}{c}\% \% \\
80.5\end{array}$ & $\begin{array}{c}\% \\
76.9\end{array}$ & $\begin{array}{l}\% \\
77.3\end{array}$ & $\begin{array}{c}\% \\
79.9\end{array}$ & $\begin{array}{c}\% \\
73.2\end{array}$ & $\begin{array}{c}\% \% \\
73.9\end{array}$ & $\begin{array}{c}\% \\
78.2 \\
780\end{array}$ & $\begin{array}{l}\% \\
76.7\end{array}$ & $\begin{array}{c}\% \\
76.9\end{array}$ & $\begin{array}{c}\overline{\%} \\
80.6\end{array}$ & $\begin{array}{l}\% \\
81.4\end{array}$ \\
\hline 73.8 & 72.6 & 74.7 & 73.6 & 73.1 & 74.7 & 69.5 & 68.1 & 69.8 & 66.5 & 65.6 & 67.1 & 60.8 & 61.0 & $\begin{array}{c}66.3 \\
(57.8)\end{array}$ & 69.7 & 69.9 & 73.9 & 73.3 \\
\hline 79.3 & 78.8 & 80.2 & 79.3 & 79.5 & 80.9 & 75.8 & 75.2 & 77.6 & 73. 2 & 73.7 & 75.8 & 68.2 & 69.8 & $\begin{array}{c}75.8 \\
(65.9)\end{array}$ & 76.0 & 73.9 & 79.2 & 79.7 \\
\hline 73.6 & 72.8 & 74.1 & 73.2 & 72.7 & 74.4 & 67.9 & 66.0 & 69.0 & 63.0 & 63.7 & 65.9 & 54. 2 & 53.0 & $\begin{array}{c}66.7 \\
(48.9)\end{array}$ & 68.1 & 66.9 & 73.0 & 72.7 \\
\hline 68.2 & 66.6 & 70.3 & 65.9 & 63.9 & 68.1 & 56.2 & 52.1 & 56.7 & 50.5 & 51.5 & 53.4 & 41.6 & 38.0 & $\begin{array}{c}54.8 \\
(37.4)\end{array}$ & 66.0 & 67.2 & 66.5 & 65.8 \\
\hline 74.1 & 73.1 & 76.2 & 71.9 & 71. 2 & 73.9 & 61.4 & 60.5 & 62.7 & 54.6 & 55.1 & 67.0 & 46.4 & 46.8 & $\left|\begin{array}{c}74.0 \\
(58.6)\end{array}\right|$ & 70.8 & 71.9 & 72.8 & 72.8 \\
\hline 66.7 & 66.6 & 69.8 & 67.7 & 67.6 & 69.8 & 67.6 & 64.9 & 68.6 & 64.4 & 62.9 & 66.6 & 61.2 & 60.1 & $\begin{array}{c}64.0 \\
(60.4)\end{array}$ & 61.9 & 63.3 & 67.9 & 66.4 \\
\hline 60.9 & 59.8 & 63.6 & 61.9 & 61.5 & 64.2 & 62.5 & 62.2 & 65.2 & 62.6 & 61.6 & 64.6 & 60.1 & 60.1 & $\begin{array}{c}62.4 \\
(62.0)\end{array}$ & 51.6 & 51.4 & 61.5 & 62.4 \\
\hline 37.7 & 32.1 & 40.3 & 39.4 & 34.9 & 40.9 & 40.2 & 33.0 & 40.9 & 38.6 & 29.0 & 37.6 & 35.2 & 16.7 & 33.7 & 24.3 & 29.5 & 39.0 & 32.2 \\
\hline 34.2 & (u. v. ) & 36.9 & $\begin{array}{r}36.1 \\
18.1 \\
\end{array}$ & $\begin{array}{r}\text { (u. v. ) } \\
7.8\end{array}$ & $\begin{array}{l}37.9 \\
11.5\end{array}$ & 35.1 & v.) & 3.8 & 28.1 & (u. v.) & 30.4 & & & & (u. v.) & 28.5 & & \\
\hline
\end{tabular}

standard samples of the same number from the Government

e "u. v." stands for "unreal value," since the expression $1-\left(t^{2} a / t_{2 a}\right)$ had a negative value
in these cases. Reflectance was calculated from the refractive index for yellow light, $n=1.5157$. 
TABLE 3.-Transmissions data for the sheet materials

\begin{tabular}{|c|c|c|c|c|c|c|c|c|c|c|c|c|}
\hline \multirow{3}{*}{$\underset{\text { material }}{\text { Number of sheet }}$} & \multicolumn{12}{|c|}{ Transmissions at- } \\
\hline & \multicolumn{2}{|c|}{ Infrared } & \multicolumn{2}{|c|}{$623 \mathrm{~m} \mu$} & \multicolumn{2}{|c|}{$546 \mathrm{~m} \mu$} & \multicolumn{2}{|c|}{$436 \mathrm{~m} \mu$} & \multicolumn{2}{|c|}{$405 \mathrm{~m} \mu$} & \multicolumn{2}{|c|}{$365 \mathrm{~m} \mu$} \\
\hline & $t_{a}$ & $t_{2 a}$ & $t_{a}$ & $t_{2 a}$ & $t_{\alpha}$ & $t_{3 a}$ & $t_{\mathrm{s}}$ & $\begin{array}{c}t_{a b} \text { or } \\
t_{2 a}\end{array}$ & $t_{a}$ & $\begin{array}{c}t_{a b} \text { or } \\
t_{2 a}\end{array}$ & $t_{a}$ & $\begin{array}{c}t_{a b} \text { or } \\
t_{2 a}\end{array}$ \\
\hline $\begin{array}{l}1215 \\
1214 \\
1191 \\
1170 \\
1133 \\
128 \\
1002 \\
198 \\
200 \\
202\end{array}$ & $\begin{array}{l}0.244 \\
.303 \\
.257 \\
.334 \\
.339 \\
.283 \\
.363 \\
.488 \\
.687 \\
.624 \\
- \\
-. .-\end{array}$ & $\begin{array}{r}0.136 \\
.170 \\
.137 \\
.192 \\
.199 \\
.157 \\
.210 \\
.313 \\
.510 \\
.418\end{array}$ & $\begin{array}{r}0.167 \\
.229 \\
.173 \\
.250 \\
.270 \\
.213 \\
.292 \\
.370 \\
.582 \\
.586 \\
-\end{array}$ & $\begin{array}{r}0.078 \\
.111 \\
.078 \\
.130 \\
.136 \\
.101 \\
.158 \\
.219 \\
.394 \\
.390 \\
- \\
-\end{array}$ & $\begin{array}{c}0.153 \\
.212 \\
.158 \\
.227 \\
.240 \\
.187 \\
.279 \\
.347 \\
.556 \\
.555 \\
.9260 \\
.9 .9285\end{array}$ & $\begin{array}{r}0.067 \\
.095 \\
.067 \\
.109 \\
.101 \\
.073 \\
.143 \\
.198 \\
.364 \\
.352 \\
.868 \\
\text { b. } 867\end{array}$ & $\begin{array}{r}0.114 \\
.157 \\
.111 \\
.158 \\
.148 \\
.104 \\
.240 \\
.304 \\
.494 \\
.419 \\
-\end{array}$ & $\begin{array}{l}0.0575 \\
.068 \\
.0535 \\
.0675 \\
.0545 \\
.041 \\
.104 \\
.150 \\
.287 \\
.195 \\
-\end{array}$ & $\begin{array}{c}0.096 \\
.127 \\
.087 \\
.118 \\
.107 \\
.065 \\
.2185 \\
.277 \\
.460 \\
.274\end{array}$ & $\begin{array}{l}0.042 \\
.047 \\
.036 \\
.043 \\
.034 \\
.024 \\
.0815 \\
.126 \\
.241 \\
.081 \\
- \\
-\end{array}$ & $\begin{array}{c}0.069 \\
.083 \\
.051 \\
.062 \\
.0585 \\
.0285 \\
.1765 \\
.2395 \\
.392 \\
.033\end{array}$ & $\begin{array}{l}0.023 \\
.024 \\
.0165 \\
.018 \\
.015 \\
.009 \\
.0504 \\
.090 \\
.170 \\
.009 \\
-\end{array}$ \\
\hline
\end{tabular}

a Measured transmissions of diffusely incident radiant energy for 1 sheet are given as $t_{a}$, for 2 sheets of the same material as $t_{2 a}$, and for the combination of the various materials with No. 128 as $t_{a b}$. 'This last combination was used for the first 6 papers at 436,405 , and $365 \mathrm{~m} \mu$. See text for further details.

b These values were obtained with light of normal incidence.

All of the calculated reflectances (reflectances calculated from transmissions) in table 2 were obtained by substitution of the measured transmissions, some of which are given in table 3 , into eq 6 or 7 . These data will be analyzed in following sections as to significance and pertinent factors. Equation 7 was used for reflectances at 436, 405, and $365 \mathrm{~m} \mu$ for papers $1215,1214,1191,1170,1133$, and 1136, using paper 128 as sheet $a$. For all other cases $t_{2 a}$ was feasibly large (greater than 0.05) and the reflectances were calculated by means of eq 6. At 623 and $546 \mathrm{~m} \mu$ the values calculated with both equations for the first six papers agreed well without any noticeable trend.

The reflectance, $R_{c}$, of the lacquered gold-selenium receiving surface of the General Electric cell was obtained as follows: Since the images reflected by the cell surface were fairly regular, $R_{c}$ was determined relative to a piece of Corex- $D$ glass. A beam was so focused, by means of a lens, that after $10^{\circ}$ incidence upon the cell surface and reflection at $10^{\circ}$, the image was projected upon the center of another cell which measured the intensity of the reflected beam. A third cell was used to compensate for intensity fluctuations. By repeating the measurement with a piece of Corex- $D$ glass at various wavelengths, the following ratios of $R_{c}$ to $R_{\text {Corex-D }}$ were obtained, for the indicated wavelengths: $365 \mathrm{~m} \mu, 0.85 ; 436 \mathrm{~m} \mu, 0.92 ; 578 \mathrm{~m} \mu, 0.96 ; 623 \mathrm{~m} \mu, 1.0$; infrared, 1.27. Two other cells gave essentially the same reflectance ratios.

From the reflectance of the Corex- $D$ glass, 0.085 (manufacturer's data), the reflectance of the cell surface for normal incidence may be calculated. The use conditions of the cell are such, however, that the reflectance for diffuse incidence should be used for $R_{c}$. The values of $R_{c}$ for normal incidence represent minimum values; maximum values may be obtained by weighting, from $\theta=0$ to $\theta=\pi / 2$, the values of the reflectances of the cell for various angles of incidence.

The relationship between $R_{c}$ and angle of incidence, $\theta$, was found in the following way: A small spot of light of wavelength $578 \mathrm{~m} \mu$ was focused on the surface of the cell, which could be rotated through known angles. The cell circuit was balanced against the compen- 
sating cell for normal incidence, and readings were then taken of the cell response at the various angles in terms of that for normal incidence. From this the variation in $R_{c}$ with $\theta$, angle of incidence, could be computed, based upon $R_{c}$ at normal incidence, 0.082 , for this wavelength. The values are recorded in table 4.

TABLE 4.-Reflectance of receiving surface, $R_{c}$, of light-sensitive cell as a function of the angle of incidence, $\theta$, at $578 \mathrm{m \mu}$

\begin{tabular}{|c|c||c|c|}
\hline$\theta$ & $R_{o}$ & $\theta$ & $R_{c}$ \\
\cline { 2 - 4 } Degrees & & Degrees & \\
0 & 0.082 & 40 & 0.088 \\
10 & .082 & 50 & .097 \\
20 & .083 & 60 & .118 \\
30 & .084 & 70 & .146 \\
\hline
\end{tabular}

From the data in table 4 , and from the reasonable assumption that $R_{c}=0.2$ at $\theta=80^{\circ}$, which value is not heavily weighted in any case, the reflectance of the cell for completely diffused illumination may be computed, using the method described by McNicholas [17], and applied by Judd and Gibson [18] to a similar problem; by

$$
R_{c \text { (diffused })}=\frac{\sum_{0}^{\pi / 3} R_{\theta} \sin 2 \theta}{\sum_{0}^{\pi / 3} \sin 2 \theta}=0.107 \text {. }
$$

This value represents the upper limit corresponding to completely diffused illumination, which is, in general, not attained.

Great accuracy in the value for $R_{c}$ is, however, not necessary, inasmuch as the correction factor, $\frac{1}{2} R_{c}\left(t_{a}^{2} / t_{2 a}\right)\left(1-t_{2 a}\right)$, usually contributes less than 2 percent in eq 6 . For the present purposes, therefore, the value 0.09 , somewhat less than intermediate between the two extremes, was adopted for $R_{c}$ at $578 \mathrm{~m} \mu$. This led to the following values for $R_{c}$ at the other wavelengths: $365 \mathrm{~m} \mu, 0.08 ; 436 \mathrm{~m} \mu, 0.085 ; 623 \mathrm{~m} \mu$, $0.095 ; 850 \mathrm{~m} \mu, 0.12$. These values were used in eq 6 and in the calculations of $T_{a}$ in eq 7 .

\section{CALCULATED REFLECTANCES FOR DIFFUSE AND NORMAL INCIDENCE}

The two sets of calculated reflectance values in table 2 correspond to the two types of illumination used, namely diffuse and normal incidence, although it should be noted that even in the latter case the second sheet of a combination is illuminated diffusely to the extent that the first sheet acts as a diffuser. The transmission values for diffuse incidence are given in table 3 ; those for normal incidence were omitted for the sake of brevity.

As it was pointed out previously, the directly measured reflectances were intended to serve as a standard of comparison for the calculated reflectances. Such a comparison is strictly valid only if the geometrical conditions involved in both cases are identical. This is, however, not the case in the present work, inasmuch as the directly measured reflectances correspond to the condition of normal incidence and diffuse viewing (or, what is numerically the same for the papers, normal 
incidence and $45^{\circ}$ viewing), whereas the calculated reflectances correspond to the condition of diffuse incidence and diffuse viewing. The latter condition obtains, to a varying extent, in the transmission measurements with normal incidence, but the reflectances calculated therefrom involve errors which will be discussed subsequently.

It is not to be expected, however, that the values corresponding to the two sets of geometrical conditions should be greatly different. McNicholas [17], using diffuse incidence (undispersed incandescentlamp light), computed that the diffuse reflectances of a variety of matte materials were, in general 1- to 3-percent reflectance higher than reflectance in the direction normal to the surface, which latter condition is equivalent to normal incidence and diffuse viewing, according to the Helmholtz reciprocity relation.

The samples studied by McNicholas were opaque or mounted on opaque backings, and had surface characteristics different from those of matte papers. It was found, however, that the materials of the present study behave similarly. This can be seen, although indirectly, from a comparison of the transmissions of various typical papers for normal and diffuse incidence, given in table 5 , in which the first and last values in each column are to be compared in the present connection.

TABLE 5.-Transmission of papers as a function of angle of incident light at $578 m \mu$

\begin{tabular}{|c|c|c|c|}
\hline \hline \multirow{2}{*}{$\Theta$} & \multicolumn{3}{|c|}{ Measured transmissions $\left(t_{a}\right)$} \\
\cline { 2 - 3 } & Paper 198 & Paper 1133 & Paper 1215 \\
\hline Degrees & & & \\
0 & 0.607 & 0.268 & \\
10 & .600 & .264 & 0.160 \\
20 & .589 & .256 & .158 \\
30 & .569 & .243 & .154 \\
40 & .547 & .228 & .141 \\
50 & .528 & .213 & .134 \\
55 & .518 & .206 & .131 \\
60 & $\mathrm{~s} .517$ & $\mathrm{a} 202$ & $\mathrm{a}$ \\
70 & .542 & .203 & .132 \\
80 & .680 & .241 & .156 \\
Diffused & .569 & .242 & .150 \\
\hline
\end{tabular}

a The increases in $t_{a}$ with $\theta$ at angles greater than $60^{\circ}$ are reproducible but probably do not represent real characteristics of papers. They are apparently the result of the particular method of measurement, which consisted in varying the angle of the measuring cell and balancing the circuit at each angle with no paper. Beyond $60^{\circ}$ the specular reflectance of the bare cell surface appears to increase much more rapidly with $\theta$ than that of the paper, so that the cell response per unit of radiant flux is greater with than without the paper. At angles below $60^{\circ}$, however, such an effect would be negligible, since the reflectance of the cell changes only slightly with $\theta$ at the smaller angles.

The results in table 2 show that the reflectances calculated from transmissions for diffuse incidence are higher than the directly measured reflectances by 1- to 3-percent reflectance, except in the extreme violet and ultraviolet, where the differences are, in general, much greater, and will be shown to be due to fluorescence effects. The values in parentheses for $365 \mathrm{~m} \mu$ demonstrate the general result of correcting for fluorescence.

The reflectances, calculated from transmissions for normal incidence, are seen to be in good agreement with the directly measured reflectances, with the exception of the tissue paper, 198, and the organic plastic, 200, for which agreement is very poor, especially in the case of 200 , for which no real values could be calculated. This is explained by the fact that the values for $t_{a}$ for these sheets are much higher for 
normal than for diffuse incidence (as shown in table 5) and are raised to the second power, whereas the corresponding values for $t_{2 a}$, which enter eq 1 to the first power, are more nearly equal, since the second sheet of the combination is illuminated diffusely to a greater or less extent, by the first sheet. Thus, for normal incidence, the expression $1-\left(t_{a}^{2} / t_{2 a}\right)$ assumes low or even negative values for very transmissive sheets, but for most papers yields values which are just sufficiently low to be in fortuitous agreement with directly measured reflectances.

The departure from the simple theory, when normal incidence is used, is thus seen to be due to a change in the value of $T_{a}$ as a consequence of the change in geometrical distribution of the radiant energy in passing through the first sheet.

This effect occurred in all cases in normal incidence, except for the clear glass, but it was less pronounced for the thicker or more diffusing papers, since such sheets exhibited less difference in $t_{a}$ for normal and diffuse incidence. Furthermore, the mathematical form of eq 1 is such that its value is much less sensitive to this type of effect for sheets of high or medium reflectance than for sheets of low reflectance.

Another effect of using normal incidence, tending to compensate the one just discussed, arises from the fact that the photosensitive surface of the measuring cell has a smaller response for diffused light, as transmitted by papers, than for an equal flux of normally incident light. Since the photoelectric circuit was balanced at 100-percent transmission with no paper, the light was perpendicularly incident; but in a measurement with a diffusing material the light was at least partially diffused. Thus for normal incidence all values for $t_{a}$ and $t_{2 a}$ were too low by the same fractional amount, leading to higher values for $R_{a}$.

Another effect which tended to give high values for $R_{a}$ was that of fluorescence, as will be shown later in section 5 .

The fact that good agreement is obtained between the reflectances calculated from transmission values for normal incidence and the directly measured reflectances is of practical rather than theoretical interest, inasmuch as this agreement is due to a compensation of errors.

The experiments with the glass sample, 202, aside from demonstrating the validity of eq 6 for very low reflectances, also show that valid results are obtainable for normally incident light as long as its geometric distribution is not altered in passing through the first sheet.

$R_{a}$ for the glass for diffused light is higher than for normal incidence. This is in agreement with the theoretical conclusions of Judd and Gibson [18], who present data, obtained in another manner, from which it may be calculated that the glass they used had a reflectance of 12.6 percent for diffused light. It should be pointed out, however, that the present method does not lend itself to precision at these low reflectances owing to the form of the expression.

\section{EFFECT OF THICKNESS OF SHEETS}

In the case of the relatively thick organic plastic sheet, 0.023 in., an appreciable quantity of light may be lost edgewise. If $x$ is the fraction of light not lost edgewise, in each sheet, then $x T_{a}$ will enter the numerator in eq 1 , and $x^{2} T_{2 a}$ will enter the denominator. Since the former is then squared, it is obvious that $x$ cancels and that this type of loss does not invalidate eq 1. 
Two other types of side losses are conceivable; one between the sheet or sheets and the cell, and the other between the two sheets. It can be shown that the former effect tends to raise the calculated reflectances and the latter tends to lower them. They thus tend to compensate and with the present experimental arrangement were probably negligible.

\section{EFFECT OF FLUORESCENCE}

The effect of fluorescence upon directly measured paper reflectance was studied at the Institute of Paper Chemistry [19], where it was found that large amounts of near infrared fluorescence arose from papers illuminated with incandescent-lamp light. In the present study, however, very little effect from infrared fluorescence should be noted, since this type of cell used is only about one-thirtieth to one-fiftieth as sensitive to infrared as to visible energy.

The papers included in the present study, however, were found to fluoresce markedly in the visible region when illuminated with $365-\mathrm{m} \mu$, ultraviolet. This was determined as follows. The circuit previously described for measuring transmissions was used. A filter which had a spectral transmission of practically zero at $365 \mathrm{~m} \mu$, but which transmitted rather freely at longer wavelengths, was placed between the illuminated sheet or sheets and the measuring cell. Thus only fluorescent energy was measured.

Not all of the fluorescent energy was measured however, since the filter, whose spectral characteristics are given in a footnote of table 6, had an average energy transmission of about one-half in the visible region. Therefore, the measured values for fluorescent energy for each sheet of paper, and for the combinations of the various sheets with a sheet of paper 128, were multiplied by a factor of 2 , since additional experiments (data not given) with other filters, which cut off at various longer wavelengths, showed that the fluorescent energy was approximately equally distributed over the visible region. The corrected values are shown in table 6 .

The values for fluorescence thus obtained are obviously included in the values for $t_{a}$ and $t_{a b}$ or $t_{2 a}$ at $365 \mathrm{~m} \mu$ in table 3 . When the latter are corrected for fluorescence and when the corrected transmissions are substituted into eq 7 (or eq 6 for papers 128 and 1002), the values for calculated reflectance for diffuse incidence are in better agreement with the directly measured reflectances than when fluorescence is not considered. The recalculated reflectances are given in parentheses in table 2. The calculated reflectances for normal incidence were not corrected, since fluorescence is one of the compensating factors resulting in fortuitous but useful agreement with directly measured reflectances.

For papers of very low transmission, however, this method does not yield dependable values for reflectance in regions causing fluorescence, owing to the fact that inaccuracies in the values for fluorescence lead to magnified errors in reflectance if the values for $t_{a b}$ or $t_{2 a}$ are very small. When $t_{a b}$ or $t_{2 a}$ is 0.04 or larger, however, fluorescence has only small or negligible effects upon the calculated reflectances. Thus, eq 6 or 7 may be used for calculating the reflectances of papers such as 128,198 , or 1002 in the $365-m \mu$ ultraviolet with only small errors caused by neglecting the fluorescence. 
TABLE 6.-Fluorescence of papers caused by 365-mu ultraviolet

\begin{tabular}{|c|c|c|}
\hline \multirow{2}{*}{ Number of paper } & \multicolumn{2}{|c|}{$\begin{array}{l}\text { Fluorescent light, a ex- } \\
\text { pressed in transmission } \\
\text { units b }\end{array}$} \\
\hline & 1 sheet & $\begin{array}{c}1 \text { sheet plus } \\
\text { paper } 128\end{array}$ \\
\hline $\begin{array}{l}1215 \\
1114 \\
11701 \\
1133 \\
1136 \\
1002\end{array}$ & $\begin{array}{l}0.002 \\
.004 \\
.002 \\
.006 \\
.006 \\
.005 \\
.003 \\
.007\end{array}$ & $\begin{array}{r}0.003 \\
.004 \\
.003 \\
.005 \\
.004 \\
.003 \\
.003 \\
.007\end{array}$ \\
\hline
\end{tabular}

a The ultraviolet incident upon the papers was excluded from the measurements by means of a 10-mm layer, contained in a glass cell, of 0.65 molar cupric chloride solution at $26^{\circ} \mathrm{C}$, which has the following transmittances (unpublished data): at $365 \mathrm{~m} \mu, 0.0005$; at $405 \mathrm{~m} \mu, 0.176$; at $436 \mathrm{~m} \mu, 0.738 ;$ at $546 \mathrm{~m} \mu, 0.788$; at $578 \mathrm{~m} \mu, 0.447$; at $623 \mathrm{~m} \mu, 0.041$; at $691 \mathrm{~m} \mu, 0.005$; at 750 to $1400 \mathrm{~m} \mu, 0.000$.

b The values in this table are expressed in the same units as those of table 3 and thus may be subtracted directly from the values for $t_{a}, t_{a b}$, or $t_{2 a}$ to obtain the corresponding transmission values for the incident ultraviolet.

\section{RESULTS OBTAINED BY USING HETEROGENEOUS (“WHITE”) LIGHT AND INFRARED}

The spectral distribution of heterogeneous ("white") light is usually altered by selective absorption in passing through a sheet of paper. This renders eq 1 theoretically inapplicable for such light, inasmuch as $T_{a}$ and $R_{a}$ may be changed by the first sheet. It was of interest from a practical standpoint, however, to determine the extent to which eq 1 could nevertheless be relied upon under these conditions. The reflectances in table 2 for normally incident heterogeneous light were calculated by using eq 6. A comparison with the directly measured reflectances shows that eq 1 is very useful for such measurements, except for very transmissive papers, such as 198, for which diffuse incidence must be used.

No comparison with directly measured reflectances was possible in the infrared, inasmuch as no standard of diffuse reflectance for the infrared is available, and inasmuch as the photoelectric responses in this region were too weak for unamplified measurement of reflectance, although they sufficed for measurement of transmission.

It should be noted, however, that the two principal causes for departure from the simple theory, namely fluorescence and change in geometric distribution during transmission, are not expected to be appreciable in the infrared. Errors due to fluorescence would necessarily be very small in this region for a variety of reasons, and the slight effect of changing the geometric distribution is evident from the results in table 2 .

The writer takes pleasure in acknowledging the advice and comments of Deane B. Judd, of the Photometry and Colorimetry Section.

\section{REFERENCES}

[1] Kasson S. Gibson, Survey of spectrophotometers, Paper Trade J. 111, 135 (Sept. 5, 1940).

[2] J. A. Van den Akker, Survey of abridged spectrophotometers, Paper Trade J. 111, 142 (Sept. 12, 1940). 
[3] A. H. Taylor, Measurement of reflection factors in the ultraviolet, J. Opt. Soc. Am. 21, 776 (1931).

[4] M. Gurevich, Ueber eine rationelle Klassification der lichstreuenden Medien, Physik. Z. 31, 753 (1930).

[5] T. Smith, The hiding power of diffusing media, Trans. Opt. Soc. 33, 150 (1931-32).

[6] G. G. Stokes, On the intensity of light reflected from or transmitted through a pile of plates, Proc. Roy. Soc. (London) 11, 545 (1860-62).

[7] H. J. Channon, F. F. Renwick, and B. V. Storr, The behavior of scattering media in fully diffused light, Proc. Roy. Soc. (London) [A] 94, 222 (1918).

[8] J. W. Ryde and B. S. Cooper, Scattering of light by turbid media, Proc. Roy. Soc. (London) $[A], \mathbf{1 3 1}, 451$ (1931).

[9] Frank Benford, Reflection and transmission by parallel plates, J. Opt. Soc. Am. \%, 1017 (1923).

[10] P. Kubelka and F. Munk, Ein Beitrag zur Optik der Farbanstriche, Z. tech. Physik. 12, 593 (1931).

[11] F. A. Steele, Optical characteristics of papєr, Paper Trade J. 100, 151 (Mar. $21,1935)$.

[12] Deane B. Judd, Optical specification of light-scattering materials, J. Research NBS 19, 287 (1937) RP1026.

[13] Merle B. Shaw and Martin J. O'Leary, Effect of filling and sizing materials on stability of book papers, J. Research NBS 21, 671 (1938) RP1149.

[14] B. A. Brice, Potentiometer circuit for two barrier layer cells, Rev. Sci. Instr. 8,279 (1937).

[15] J. S. Preston, The reflection of magnesium oxide, Trans. Opt. Soc. 31, 15 (1929-30).

[16] Kasson S. Gibson and Harry J. Keegan, Calibration and operation of the General Electric Recording Spectrophotometer of the National Bureau of Standards, J. Opt. Soc. Am. 28, 372 (1938).

[17] H. J. McNicholas, Absolute methods in reflectometry, BS J. Research 1, 50 (1928) RP3.

[18] Deane B. Judd and Kasson S. Gibson, Note on the effect of a cover glass in reflectance measurements, J. Research NBS 16, 261 (1936) RP872.

[19] Institute of Paper Chemistry Report No. 8, Adaptability of the G. E. Reflection Meter as Color Analyzer. Also in Paper Trade J. 104, 245 (May 6, 1937); 104, 255 (May 13, 1937); 104, 271 (May 20, 1937).

Washington, September 16, 1941. 